\title{
Допринос Универзитетске библиотеке "Светозар Марковић” сталном стручном усавршавању запослених у библиотечко-информационој делатности
}

\author{
Александра Поповић \\ popovic@unilib.rs \\ Драгана Столић \\ stolic@unilib.rs \\ Дејана Каваја Станишић \\ kavaja@unilib.rs \\ Универзитет у Београду \\ Универзитетска библиотека „Светозар Марковић“, Београд
}

\begin{abstract}
Сажетак
У раду је представљена едукативна активност Универзитетске библиотеке „Светозар Марковић” намењена запосленима у библиотечко-информационој делатности. Као матична за високошколске библиотеке на територији Србије, она се систематски и организовано бави стручним усавршавањем библиотекара у оквиру мреже академских библиотека. Успостављањем система акредитације у библиотечко-информационој делатности 2013. године, Библиотека је своју образовну делатност додатно развила, обогатила и унапредила, предлагањем и спровођењем значајног броја семинара које је похађао велики број корисника. У периоду од 2014. до 2018. године реализовано је 19 програма у којима је учествовало 2306 полазника. Досадашња пракса Библиотеке у овом сегменту рада указује на важност интерактивног, иновативног и флексибилног приступа обуци библиотечких радника, како би они лакше могли да савладају изазове са којима се суочавају, међу којима су сада најактуелнији: усвајање принципа отвореног приступа, разумевање основних појмова ауторског права, познавање нових информационих технологија значајних за библиотечке раднике и њихове све захтевније кориснике, коришћење комерцијалних и некомерцијалних електронских сервиса и сл.
\end{abstract}

Кључне речи: Универзитетска библиотека „Светозар Марковић”, акредитовани семинари, стручно усавршавање едукација, библиотекари, информациона писменост, целоживотно учење, отворени приступ, информациони системи, ауторско право

\section{Увод}

Доношењем Правилника о сталном стручном усавршавању запослених у библиотечко-информационој делатности 2013. године, утврђен је начин „акредитације програма стручног усавршавања”, њиховог „организовања и спровођења” и истакнута је обавеза запослених да се стално усавршавају за обављање стручних послова у библиотеци. Програми се акредитују од 2014. године у складу са назначеном процедуром и спроводе у библиотекама на територији Србије. ${ }^{1}$ Овај вид активности, чини се, даје одговарајуће резултате, о чему сведоче и подаци

„Правилник о сталном стручном усавршавању у библиотечко-информационој делатности”, Службени іласник РС број 18 (2013), преузето 2. 4. 2019, http://www.kultura.gov.rs/cyr/dokumenti/propisi-iz-oblasti-kulture/pravilnik-o-stalnom-strucnom-usavrsavanju-ubibliotecko-informacionoj-delatnosti-. 
објављени у Гласнику Нароgне библиошеке Србије, прикупљени након анкете о реализованим семинарима спроведеним у мрежи матичних библиотека на територији Републике Србије у периоду од 2014. до 2017.2

Иако дати у сумарном приказу, подаци везани за Универзитетску библиотеку „Светозар Марковић" указују на њен допринос процесу реализације акредитованих програма, јер се број курсева које је предложила ова установа непрекидно повећавао: од 2014. године, када је Библиотека реализовала само један, преко 2015, када су у понуди била четири, до периода 2016-2018. године, када је акредитовано по пет семинара годишње. ${ }^{3}$ Откако је установљена процедура акредитације, ниједан програм који је предложила Универзитетска библиотека није одбијен, а број запослених у библиотечко-информационој делатности који их похађају повећавао се и, на годишњем нивоу, константно достиже број од неколико стотина. Број полазника у односу на годину похађања курсева приказан је на Графикону 1.

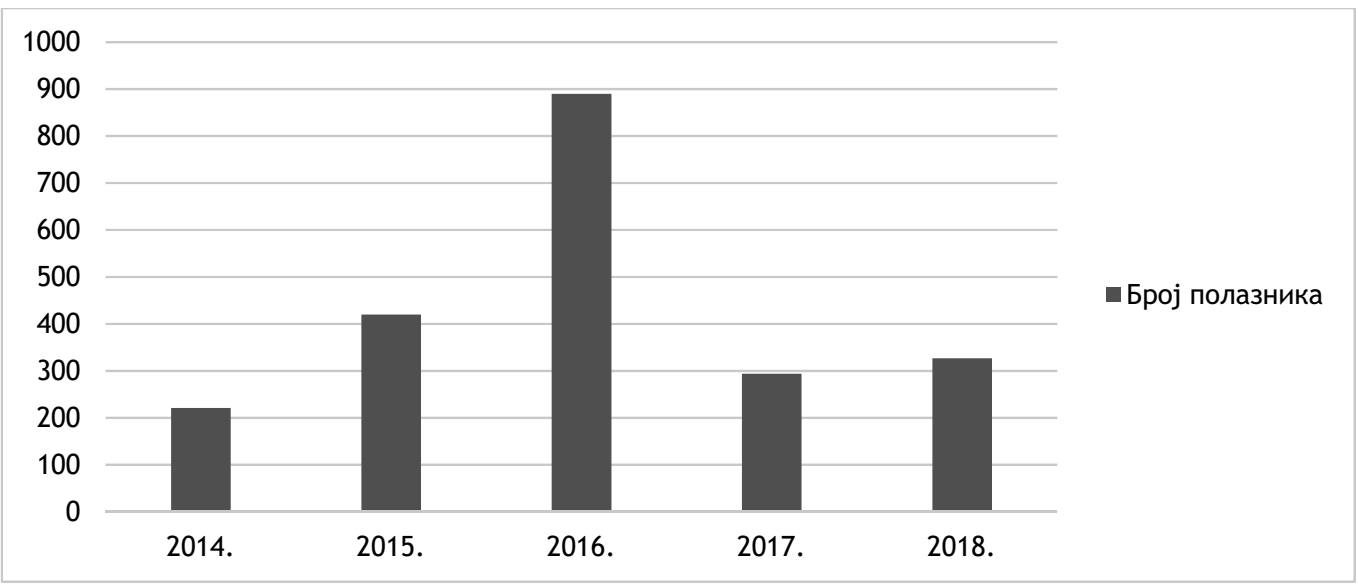

Графикон 1. Број полазника акредитованих семинара по годинама

\section{Образовне активности у Универзитетској библиотеци „Светозар Марковић”}

Акредитовани семинари сматрају се важним сегментом укупног рада Универзитетске библиотеке, који се развија са посебном пажњом. Ипак, из перспективе историјског развоја установе, они се могу третирати као природни наставак и логична фаза у напретку вишедеценијске активности, која се у највећем степену развијала кроз свакодневни рад Одељења за научне информације и рефералну делатност, односно читавог Сектора за рефералну делатност, матичну делатност и развој, у чијем саставу је ово одељење било. Реч је, пре свега, о различитим видовима курсева који су се спроводили према корисницима и према запосленима. Штавише, управо развој Одељења у правцу образовања наметнуо је потребу за реорганизацијом, што је потом довело до његове поделе и формирања новог Одељења за научне информације и едукацију 2007. године. Оваква структурна измена омогућила је да се фокус стави на образовно-инструктивну делатност, на њено усложњавање и усмеравање према различитим циљним групама. Заједно са Одељењем за матичну делатност, као организационом јединицом унутар истог сектора, чији је домен рада мрежа високошколских библиотека и професионално усавршавање запослених, Одељење је наставило да негује разнолику и богату образовну понуду.

\footnotetext{
2 Добрила Бегенишић, „Акредитовани програми сталног стручног усавршавања у библиотечко-информационој делатности у Србији (2014-2017)“, Гласник Нарояне библиоешеке Србије 17, бр. 20 (2018): 123-143.

3 За 2019. годину предложено је и акредитовано 5 семинара: Универзитетска библиотека „Светозар Марковић“, Акреgиш̄овани курсеви за библиошеекаре у 2019. іобини, преузето 2. 4. 2019, http://www.unilib.rs/usluge/edukacija/.
} 
Поповић А. и др. „Допринос УБ 'Светозар Марковић' сталном стручном усавршавању

запослених у библиотечко-информационој делатности", 32-39

Едукативне активности у ширем смислу никада нису биле везане искључиво за рад једног одељења, већ су се у различитим видовима спроводиле и у другим организационим јединицама Библиотеке (нпр. у Одељењу за обраду библиотечког материјала, као пракса студената Катедре за библиотекарство и информатику Филолошког факултета Универзитета у Београду; кроз различите презентације о релевантним темама као што је ауторско право и сл.). Разлоге за ову чињеницу требало би тражити у улози коју Универзитетска библиотека „Светозар Марковић" има у укупном библиотечко-информационом систему, као једна од највећих библиотека у земљи и матична за високошколске библиотеке на територији уже Србије. Успостављањем система акредитације, образовна делатност Библиотеке за библиотекаре се систематизује, развија и проширује на више начина: повећавањем броја тема, укључивањем више типова библиотека, односно проширењем домена рада изван круга академских библиотека, према јавним и националним библиотекама.

\section{Стручно усавршавање запослених у Универзитетској библиотеци „Светозар Марковић“ пре 2013. године}

Убрзан развој информационих технологија може се сматрати катализатором едукативних активности, јер се пред библиотечке раднике поставља захтев да буду стално информисани и обучавани да би могли да одговоре на свакодневне изазове и информационе потребе корисника. Као матична за више од 250 академских библиотека, Универзитетска библиотека је имала посебну обавезу да организује и спроводи различите облике усавршавања библиотекара који раде у академским, научноистраживачким институцијама. ${ }^{4}$ Током последње две деценије, Библиотека је успевала на различите начине да буде чвориште релевантних информација за своју библиотечку заједницу: кроз покретање часописа Инфошека, организовање стручних састанака, оснивање Заједнице библиотека универзитета у Србији, или објављивање

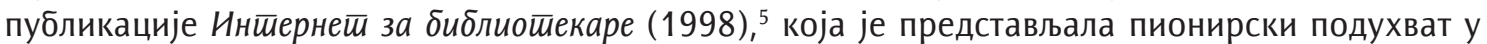
овој области. Управо ова публикација је иницирала, крајем деведесетих година прошлог века, више кратких обука за запослене у Универзитетској библиотеци, што је за неке од њих тада значило и први сусрет са интернетом као ресурсом и упознавање са новим онлајн окружењем.

Почетком 21. века, Библиотека се делимично укључила у реализацију програма Школе Б+, ${ }^{6}$ а убрзо након тога започеле су интензивније образовне активности у Библиотеци за запослене у академским библиотекама. Теме које су тада биле обрађене биле су везане претежно за категоризацију научних радова, како би библиотекари били подробније упућени у усвојене измене у начину вредновања научног рада и како би на одговарајући начин разумели библиометријске показатеље.

Успостављањем КоБСОН-а, када су се отвориле нове могућности коришћења претплаћених онлајн ресурса, организован је и низ презентација за наставнике и сараднике универзитета ради њиховог упознавања са условима и начином приступа електронским часописима и књигама. Ове две праксе - обуке за библиотекаре, на једној страни и на другој за наставно особље и истраживаче, коначно су обједињене у раду новоформираног Одељења за научне информације и едукацију 2007. године, да би убрзо биле употпуњене додатним програмима за друге групе корисника: студенте одређених студијских група, докторанде и остале.

\footnotetext{
4 „Решење о одређивању библиотека које обављају матичне функције у библиотечко-информационој делатности”, Службени іласник PC 122 (2012), преузето 2. 4. 2019, http://www.kultura.gov.rs/lat/dokumenti/propisi-iz-oblasti-kulture/ resenje-o-odredjivanju-biblioteka-koje-obavljaju-maticne-funkcije-u-bibliotecko-informacionoj-delatnosti-.

${ }^{5}$ Dušan Surla i dr., Internet za bibliotekare (Beograd: Zajednica biblioteka univerziteta u Srbiji; Novi Sad: Prirodno-matematički fakultet; Institut za matematiku, 1998).

${ }_{6}^{6}$ Škola B+, preuzeto 2. 4. 2019, http://clio.rs/b-plus/hronika/predavaci2002.htm.
} 


\section{Радионице за библиотекаре у високошколским библиотекама}

Непосредно пред примену Правилника о сталном стручном усавршавању, односно у периоду 2012-2013, у Библиотеци је одржано 38 курсева или радионица за библиотекаре, са 695 полазника. Овај број чини четвртину укупног броја едукација које је Библиотека спровела током ове две године за друге категорије полазника (студенте, наставнике, ученике): 169 различитих радионица и предавања. ${ }^{7}$

Свака од радионица имала је свој назив, програм и практичне примере, а за неке обуке библиотекари су добијали и сертификате о похађању. Одржане су следеће радионице: КоБСОН за све: уйознавање са КоБСОН-овим йорйалом, ситрании, Елечас и Елекњиїе и gруїи сервиси, Еbsco и

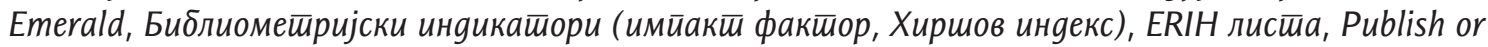

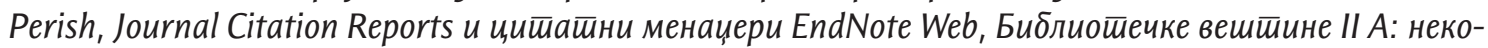
мериијални и комериијални извори информаиија и Библиотечке вешишине II B: науине информаиије - нове иеерсииекйиве иишаююа (сертификовани). Теме су прилагођаване потребама полазника и њиховом предзнању, будући да су се и међу самим библиотекарима уочавале различите потребе и интересовања.

Полазници свих курсева искључиво су били библиотекари у високошколским институцијама, али су се и међу њима издвојиле посебне групе, као што су запослени у војним установама (нпр. Војномедицинској академији или Техничко-опитном центру), што је било специфично, јер ова група запослених није имала много прилика да се усавршава у библиотечко-информационој делатности.

И поред тога што тада акредитациони процес још није започет и пред библиотекаре није формално постављан захтев да се стручно усавршавају, односно да сакупљају одређени број бодова на годишњем нивоу, овакве обуке су изазивале велико интересовање запослених у мрежи високошколских библиотека те су биле увек посећене и праћене.

Искуство са ових курсева постало је драгоцено за конципирање будућих акредитованих семинара. Истовремено, постављен је стандард у креирању и презентацији садржаја, што је укључивало примену следећих принципа:

1) Актуелност. Нако се могло учинити да се неке теме понављају (нпр. сервиси КоБСОН-а), увек су у питању били модификовани, ажурирани програми, који су настојали да укажу на новине и актуелности.

2) Практичан рад. Радионице су подразумевале коришћење рачунара и рад у сервисима. За предаваче то је значило и потребу за тимским радом, кроз комбинацију презентација и демонстрација, како би могло да се изађе у сусрет већем броју полазника.

3) Интерактивност. Радионице су увек биле замишљене као размена искустава и знања међу колегама и представљале су својеврсне "форуме" за разматрање различитих тема од интереса за библиотекаре. Овакав приступ је, чини се, био посебно важан библиотекарима који раде у мањим срединама, као што су факултетске библиотеке са једним или двоје запослених, којима су семинари били прилика да чују мишљења и ставове колега.

Прикупљена знања, праксе и методе систематизовани су и уобличени кроз семинар одржаван у периоду 2012. и 2013, када је Универзитетска библиотека спроводила програм под називом „Информациона писменост” за наставнике средњих школа и гимназија, који је одобрио Завод за унапређење образовања и васпитања. Најзад, када је у другој половини 2013. године расписан конкурс за акредитацију програма, Одељење за научне информације и едукацију је предложило први семинар, под називом Ннформациона йисмености за библиотекаре: комериијални и некомериијални елекйронски извори информација, који је потом акредитован и реализован у 2014.

7 Делимични преглед радионица доступан у: Архива Универзишешеиске библиоеиеке, преузето 2. 4. 2019, http://arhiva.unilib.rs/unilib/ edukacija/arhiva.php. 
Поповић А. и др. „Допринос УБ 'Светозар Марковић' сталном стручном усавршавању

запослених у библиотечко-информационој делатности", 32-39

\section{Акредитовани семиинари у Универзитетској библиотеци „Светозар Марковић” (2014-2018)}

Универзитетска библиотека „Светозар Марковић” је до краја 2018. године акредитовала и реализовала 19 посебних семинара за укупно 2306 полазника. Називи програма, период реализације и број полазника дати су у Табели 1.

\begin{tabular}{|c|c|c|c|c|}
\hline Бp. & Назив програма & $\begin{array}{l}\text { Година } \\
\text { реализације }\end{array}$ & $\begin{array}{l}\text { Број одржаних } \\
\text { радионица }\end{array}$ & $\begin{array}{l}\text { Укупан број } \\
\text { полазника }\end{array}$ \\
\hline 1. & $\begin{array}{l}\text { Информациона писменост у библиотекама: } \\
\text { комерцијални и некомерцијални електронски } \\
\text { извори информација }\end{array}$ & 2014. & 14 & 221 \\
\hline 2. & Метаподаци у савременом библиотекарству & 2015. & 5 & 71 \\
\hline 3. & Вики-библиотекар & 2015. & 6 & 77 \\
\hline 4. & Гугл за библиотекаре & 2015. & 12 & 213 \\
\hline 5. & Култура дигиталног маркетинга & 2015. & 5 & 59 \\
\hline 6. & $\begin{array}{l}\text { Linked Open Data и Bibframe: нови облици } \\
\text { организовања метаподатака у библиотекарству }\end{array}$ & 2016. & 5 & 249 \\
\hline 7. & Вики-библиотекар & 2016. & 6 & 81 \\
\hline 8. & Библиометрија и научни часописи & 2016. & 7 & 179 \\
\hline 9. & $\begin{array}{l}\text { Ауторско право у библиотечко-информационој } \\
\text { делатности }\end{array}$ & 2016. & 15 & 337 \\
\hline 10. & Дигитално приповедање и друштвени медији & 2016. & 4 & 44 \\
\hline 11. & RDA и BIBFRAME: библиографски опис за 21. век & 2017. & 4 & 54 \\
\hline 12. & Вики-библиотекар (акредитован на две године) & 2017. & 7 & 90 \\
\hline 13. & Библиографски алати: EndNote и Mendeley & 2017. & 2 & 35 \\
\hline 14. & Мултимедије у библиотекарству & 2017. & 6 & 46 \\
\hline 15. & $\begin{array}{l}\text { Ауторско право у библиотечко-информационој } \\
\text { делатности: повреда права и појам плагијата } \\
\text { (акредитован на две године) }\end{array}$ & 2017. & 7 & 123 \\
\hline 16. & $\begin{array}{l}\text { Ауторско право у библиотечко-информационој } \\
\text { делатности: повреда права и појам плагијата }\end{array}$ & 2018. & 4 & 132 \\
\hline 17. & Вики-библиотекар & 2018. & 3 & 50 \\
\hline 18. & Нови медији у библиотекама & 2018. & 2 & 15 \\
\hline 19. & $\begin{array}{l}\text { Дигитални репозиторијуми у библиотечко- } \\
\text { информационој делатности }\end{array}$ & 2018. & 9 & 130 \\
\hline$\Sigma$ & 19 & & 123 & 2306 \\
\hline
\end{tabular}

Табела 1. Називи програма, период реализације и број одржаних радионица и укупан број полазника

У односу на претходну праксу, реализација акредитованих семинара унела је неколико новина, међу којима је на првом месту ӣроширење и на gруїе йрофиле йолазника, који више не припадају само академским или специјалним библиотекама, већ у великој мери јавним. Према расположивим подацима за период 2014-2017, чак 51\% свих полазника (968 од 1879) били су запослени у јавним библиотекама. Знатно мањи проценат припадао је националним библиотекама, односно Народној библиотеци Србије и Библиотеци Матице српске. 
Курсеви су, потом, подразумевали конииинуирано укључивање зайослених из вище орїанизационих јеgинииа Библиошеке (Одељење обраде библиотечког материјала, Одељење за дигитализацију), што је довело до уочљиве разноврсности програма и до интензивиране сарадње међу одељењима те до израженијег интердисциплинарног приступа. Сарадња међу одељењима, током времена, проширивала се и на више институција, па су неке семинаре водили предавачи из других библиотека. Свака слична сарадња, као и сусрет са библиотекарима из других типова библиотека, омогућили су боље упознавање и разумевање специфичности и проблема рада у тим библиотечким срединама.

Искуство у реализацији акредитованих семинара указује на потребу поштовања, поред горепоменутих принципа, као што су актуелност, практичан рад и интерактивност и неколико додатних начела:

1) Иновативност. Иако су се заснивали на знању и искуствима предавача, предложени програми су увек представљали и искорак из оквира свакодневног рада и значили су усвајање нових појмова. Поједине теме су излазиле из професионалног домена библиотечке делатности, залазећи у друге научне области (нпр. ауторско право). Адекватан одговор на овако постављене захтеве је подразумевао непрекидно усавршавање предавача, истраживање и учење. $^{8}$

2) Флексибилност. Током периода реализације, предложени програми су се нужно модификовали, прилагођавајући се знању и интересовању полазника. Пошто су увек били интерактивни, они су били места где се постављају питања, а одговори који су на овај начин подстицани потом су интегрисани у њихов садржај. Предавачи су били спремни да сваком новом информацијом обогате семинар чија је реализација у току: на пример, током трајања „Ауторског права у библиотечко-информационој делатности“, сви новоусвојени прописи или нови случајеви из судске праксе унети су у план излагања; обавештење о Платформи за отворену науку је укључено у програм о дигиталним репозиторијумима одмах пошто је Министарство просвете, науке и технолошког развоја Републике Србије усвојило овај документ и сл.

3) Повратне информације. Неки од семинара су били праћени онлајн анкетама, које су, осим оцене, садржавале сугестије за њихово побољшање, што је било драгоцена повратна информација која је одмах уграђена у даљи рад. На пример, после првог акредитационог циклуса и у складу са најчешћим сугестијама, програм „Ауторско право у библиотечко-информационој делатности" је обогаћен примерима из судске праксе, што је наишло на позитиван одзив и директно утицало на даљи развој концепта овог семинара.

\section{Закључна разматрања}

Принцип доживотног учења, који се као императив поставља пред библиотекаре, кроз акредитоване семинаре је имплементиран у библиотечко-информационој делатности на систематизован и контролисан начин. У великој мери овакав приступ је допринео да Универзитетска библиотека „Светозар Марковић” учврсти своју позицију носиоца развоја у библиотечко-информационом систему земље и да буде чвориште информација и знања за кориснике и библиотечке раднике. То свакако није у несагласности са трендом у савременом академском библиотекарству према којем је „основни постулат (...) да универзитетске библиотеке морају бити пре свега оријентисане према корисницима и пружању услуга а не према прављењу

\footnotetext{
${ }^{8}$ Clarence Maybee, "Developing Librarians to Support Learning Initiatives", in IMPACT Learning: Librarians at the Forefront of Change in Higher Education (Chandos Information Professional Series, 2018), 145-156.
} 
Поповић А. и др. „Допринос УБ 'Светозар Марковић' сталном стручном усавршавању

запослених у библиотечко-информационој делатности", 32-39

збирки за које библиотекари претпостављају да ће бити коришћене“. ${ }^{9}$ Процес образовања и стицања знања ради подизања нивоа услуга и адекватног одговора на захтеве корисника вишесмеран је, динамичан и укључује библиотекаре полазнике, као и библиотекаре предаваче.

То не значи да сам систем акредитације не би требало да буде евалуиран и побољшаван и, како је речено, учињени су кораци у овом правцу. ${ }^{10}$ Питање које је искуство Универзитетске библиотеке отворило, али које за сада нема јасан и чврст одговор, јесте начин евалуације стварних ефеката ових семинара, односно реалног повећања применљивог знања, па стога и унапређење праксе библиотечких радника. Квалитет понуде акредитованих семинара, па и свих других облика библиотечке едукације, лако је проверљив, захваљујући већ примењеним механизмима, као што су анкете, евалуације полазника и, најзад, сам систем акредитације. Другачије ствари стоје када се пажња усмери према практичним резултатима ових едукација. Посматрани из те перспективе, семинари организовани у Универзитетској библиотеци, управо кроз јасно изражено настојање да је применљивост један од кључних критеријума за избор и презентацију одређене теме, рекло би се иду у добром правцу, али је потребно убудуће спровести подробнија истраживања како би се ова претпоставка и потврдила.

\section{Литература и извори:}

1. Arhiva Univerzitetske biblioteke. Preuzeto 2. 4. 2019. http://arhiva.unilib.rs/unilib/edukacija/arhiva.php.

2. Begenišić, Dobrila. „Akreditovani programi stalnog stručnog usavršavanja u bibliotečko-informacionoj delatnosti u Srbiji (2014-2017)". Glasnik Narodne biblioteke Srbije 17, br. 20 (2018): 123-143.

3. Filipi Matutinović, Stela i Aleksandra Popović. „Promene uloga visokoškolskih biblioteka“. U Informaciona pismenost $i$ doživotno učenje, urednici Aleksandra Vraneš, Gwen Alexander i Ljiljana Marković, 471-480. Beograd: Filološki fakultet Univerziteta u Beogradu; Bibliotekarsko društvo Srbije, 2008.

4. Maybee, Clarence. "Developing Librarians to Support Learning Initiatives". In Impact Learning: Librarians at the Forefront of Change in Higher Education, 145-156. Chandos Information Professional Series, 2018.

5. „Pravilnik o stalnom stručnom usavršavanju u bibliotečko-informacionoj delatnosti". Službeni glasnik br. 18 (2013). Preuzeto 2. 4. 2019. http://www.kultura.gov.rs/cyr/dokumenti/propisi-iz-oblasti-kulture/ pravilnik-o-stalnom-strucnom-usavrsavanju-u-bibliotecko-informacionoj-delatnosti-.

6. "Rešenje o određivanju biblioteka koje obavljaju matične funkcije u bibliotečko-informacionoj delatnosti“. Službeni glasnik RS br. 122 (2012). Preuzeto 2. 4. 2019. http://www.kultura.gov.rs/lat/ dokumenti/propisi-iz-oblasti-kulture/resenje-o-odredjivanju-biblioteka-koje-obavljaju-maticnefunkcije-u-bibliotecko-informacionoj-delatnosti-.

7. Surla, Dušan, Gordana Popović Bošković, Ljiljana Kovačević, Dragana Todorić i Dragan Prlja. Internet za bibliotekare. Beograd: Zajednica biblioteka univerziteta u Srbiji; Novi Sad: Prirodno-matematički fakultet, Institut za matematiku, 1998.

8. Škola B+. Preuzeto 2. 4. 2019. http://clio.rs/b-plus/hronika/predavaci2002.htm.

9. Univerzitetska biblioteka "Svetozar Marković". Akreditovani kursevi za bibliotekare u 2019. Preuzeto 6. 4. 2019. http://www.unilib.rs/usluge/edukacija/.

\footnotetext{
${ }_{9}^{9}$ Стела Филипи Матутиновић и Александра Поповић, „Промене улога високошколских библиотека“, у Ннформациона йисменосй и gоживошино уиење, ур. Александра Вранеш, Гвен Александар и Љиљана Марковић (Београд: Филолошки факултет Универзитета у Београду; Библиотекарско друштво Србије, 2008), 471-480.

10 Бегенишић, Нав. дело: 123
} 


\title{
Contribution of University Library "Svetozar Marković" to Continuing Professional Development of Employees in Librarianship
}

\begin{abstract}
Summary
This paper presents educational activity conducted by the University Library "Svetozar Marković" for employees in librarianship. As a central institution for all academic libraries in Serbia, the University Library "Svetozar Marković" systematically organizes professional development trainings for librarians within the network of academic libraries. By establishing the accreditation system in librarianship in 2013, the library has developed, enriched and improved its educational activity and conducted a significant number of seminars attended by numerous participants. Accredited seminars are considered an important segment of the overall work of the University Library. In the period from 2014 to 2018,19 programs with 2306 attendees were organized. These numbers are the results of continuity and the long term experience of the University Library "Svetozar Marković" in organizing various trainings for different target groups, mainly from academic environment (students and professors, academic librarians). The development of activities in the direction of educational programs was the main reason for major changes within the organizational scheme of the library and the establishment of the Department for Scientific Information and Education a decade ago. With the system of accreditation, educational work has spread more intensively to the other departments of the library, but it has also brought the other types of librarians into focus (librarians from public libraries). The practice of the library in this segment of work points to the importance of an interactive, innovative and flexible approach to the training of librarians, that would help them overcome the current challenges they face: adopting the principles of open access, understanding basic principles of copyright, new information technologies significant for librarians and their increasingly demanding users, the use of commercial and noncommercial electronic services, etc.
\end{abstract}

Keywords: University Library "Svetozar Marković", accredited seminars, professional development, education, librarians, information literacy, lifelong learning, open access, information systems, copyright

Примљено: 1. априла 2019.

Исправке рукописа: 12. априла 2019. Прихваћено за објављивање: 15. априла 2019. 


\section{$(0 \otimes \Theta$}

Допринос Универзитетске библиотеке „Светозар Марковић” сталном стручном усавршавању запослених у библиотечко-информационој делатности by Александра Поповић, Драгана Столић, Дејана Каваја

Станишић is licensed under a Creative Commons Attribution-NonCommercial-NoDerivatives 4.0 International License. 